\title{
PROSPECTS OF MARITIME TRANSPORT IN THE ESTABLISHMENT OF “GREEN” LOGISTICS CHAINS
}

\author{
Antoaneta Kirova \\ "Todor Kableshkov" University of Transport, Faculty of Transport \\ Management, Department "Economics and Accounting in transport", \\ Sofia, Bulgaria \\ CMESTE \\ JEL Category: L92, 018, R41
}

\begin{abstract}
Maritime transportation is dominantly focused on freight since there is no other effective alternative to the long-distance transportation of large amounts of freight. The EC encourages improvements in the sustainability of maritime transport by reducing emissions from ships, and a European maritime transport policy to be developed in the common maritime area. Based upon statistical analysis, the role of waterborne transport, and maritime in particular in the national economy is indicated, in connection with describing the attempts to introduce green logistics in Bulgaria. Special attention has been paid to the opportunities to develop sea ferryboat transport. Also, to support the rile of combined transport for a green logistics, a Cargo Ferry concept has been mentioned, developed is aiming at the removal of the barriers for transferring freight from the road to the sea, particularly on short than 500 kilometers distances, offering a cost-effective and more environmentally friendly alternative.
\end{abstract}

Keywords: waterborne transport, logistics, traffic, technological change, policy, European Union

\section{INTRODUCTION}

Europe is surrounded by many islands and four seas: the Mediterranean, the Baltic, the North, and the Black Sea, as well as two oceans: the Atlantic and the Arctic Ocean. This continent is a peninsula with thousands of kilometers of coastline - longer than any other landmass, such as the United States of America or the Russian Federation. This geographical reality means that more than twothirds of the EU's borders are coastline and the

Address of the corresponding author:

Antoaneta Kirova

帮akirova@vtu.bg waters under the jurisdiction of its Member States are larger than their terrestrial territory. Through its outermost regions, in addition to the Arctic Ocean, Europe is also present in the Indian Ocean and the Caribbean. Their maritime issues are many and affect the EU as a whole. The EU now can apply sustainable development to the oceans. To do this, the European Union can draw on the forces with which it has already paid off its maritime leadership: knowledge of the oceans, expanded experience, and the ability to take on new challenges and combine these qualities with a strong obligation to protect the resource base.

So far, our policies on maritime transport, maritime ecology, and other important areas have been 
inadequately addressed about green logistics. The purpose of the paper is to draw attention to some aspects of maritime transport and its possibilities for improvement, bearing in mind its importance for the economy of the Republic of Bulgaria.

\section{EUROPEAN TRANSPORT POLICY AND MARITIME TRANSPORT}

Maritime transportation is dominantly focused on freight since there are no other effective alternatives to the long-distance transportation of large amounts of freight.

Based on the White Paper, European policy objectives for waterborne transport mode are the following:

- Maritime: protection of high EU safety standards, rules, and regulations to reduce accidents and reduce climate and environmental impacts; improve working conditions; digitalization in the maritime services; provide safe and secure conditions of maritime services

- Inland waterways (IWW): strengthen the role of IWW, improvement of IWW markets in Europe for reduction of climate and environmental impact, high qualified staff and quality jobs, and integration of IWW in multimodal transport chains and logistics operation.

The EU maritime strategy, originally defined in 2009, was assessed in a 2016 Commission Staff Working Document (EC, 30.9.2016), covering the period 2009-2015 and providing an outlook for required future activities with main relevant areas such as:

- Maritime Safety and Security.

- Digitalization and Administrative Simplification.

- Environmental Sustainability and Decarbonisation.

- Raising the Profile and Qualifications of Seafarers and Maritime Professions.

- EU Shipping as a stronger global player.

In recent years, numerous measures were adopted in protecting the marine environment (EC, 21.1.2019). In its resolution of $5^{\text {th }}$ May 2010 on strategic goals and recommendations for the EU's maritime transport policy until 2018,
Parliament supported the Commission's approach and also required further action against abuses of flags of convenience, new rules on state aid and guidelines for ports, greater consideration of maritime routes within the TEN-Ts (particularly through the motorways of the sea), improvements in the sustainability of maritime transport by reducing emissions from ships, and a European maritime transport policy to be developed in the common maritime area (EC, 30.9.2016).

On $15^{\text {th }}$ December 2011, in the adopted Resolution "Roadmap to a Single European Transport Area" in response to the 2011 Commission White Paper, regarding maritime transport the requirements of Parliament are:

- A proposal on the "Blue Belt" (COM (2013)0510 of $8^{\text {th }}$ July 2013).

- The introduction of a European policy for short and medium sea shipping.

- The allocation of at least $15 \%$ of TEN-T funding to projects that improve sustainable and multimodal connections between seaports, inland ports, and multimodal platforms.

- In 2016 a call "Port of the Future" was made as part of the Horizon 2020 program.

The systematic growth of maritime freight traffic has been fueled by:

Competitive advantages as a mode of transport applicable separately and as a part of combined transportation chains. Maritime transport is linked to the growth of energy products' trade carried over long distances. The international trade liberalization, production specialization and industrial globalization brought forward the need for final products' transportation, which is supported mainly by combined modes of transport, based upon containers. On the other hand, containers are closely related to maritime transport, again over long distances, subject to different origins and destinations.

Technical improvements. Besides ships and maritime terminals, with their ability to handle different types of cargoes, more and more companies are developing digital platform strategies responding to the needs of ship crews, enabling the analysis and ongoing control of ship systems, the technological and economic parameters of ship voyages, the maintenance of crew wellbeing and the provision of IT to the ship. 
The integration of these platforms with the shipowners' or operators' internal IT systems allows for real-time scheduling of cargo operations, crew schedules, ship supply, routine preventive repairs, and the proper operation of ship's facilities. Unfortunately, many shipowners and shipping operators still think that digital transformation is just a matter of new technological solutions, confusing the terms "digitalization" with "business transformation" and not realizing that they lack a digital vision for the future.

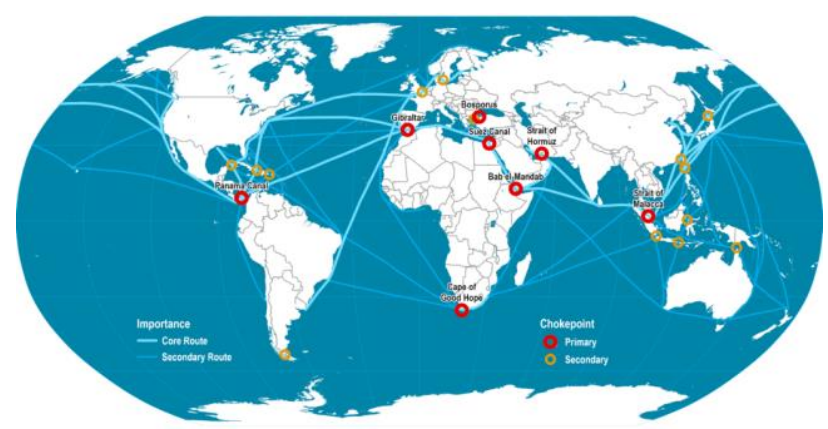

Figure 1. Main Maritime Shipping Routes Source: (Rodrigue \& Notteboom, 2017)
Economies of scale. The flexibility of ship size, as well as ship specialization, allows maritime transportation to be cost-efficient

There are three major problems with the digitalization of the shipping industry - the high value of satellite internet, its lack of speed, and the lack of a single communication standard. Excellent internet connectivity is a vital issue not only for the efficiency and optimization of ocean routes but also for the ship's smart systems. This is especially true of new experiments with "intelligent" semi-autonomous or autonomous ships conducted in the Far East and Europe. The administrative barriers to digitalization are outdated regulations, social pressure to keep crews, computer security issues, and the threat of terrorism that further delay the introduction of technological change. However, these obstacles cannot discourage the many digital startups and platforms that appear on the horizon almost daily, backed by private investors, classification societies, public and private foundations, global technology leaders, and advanced maritime nations.

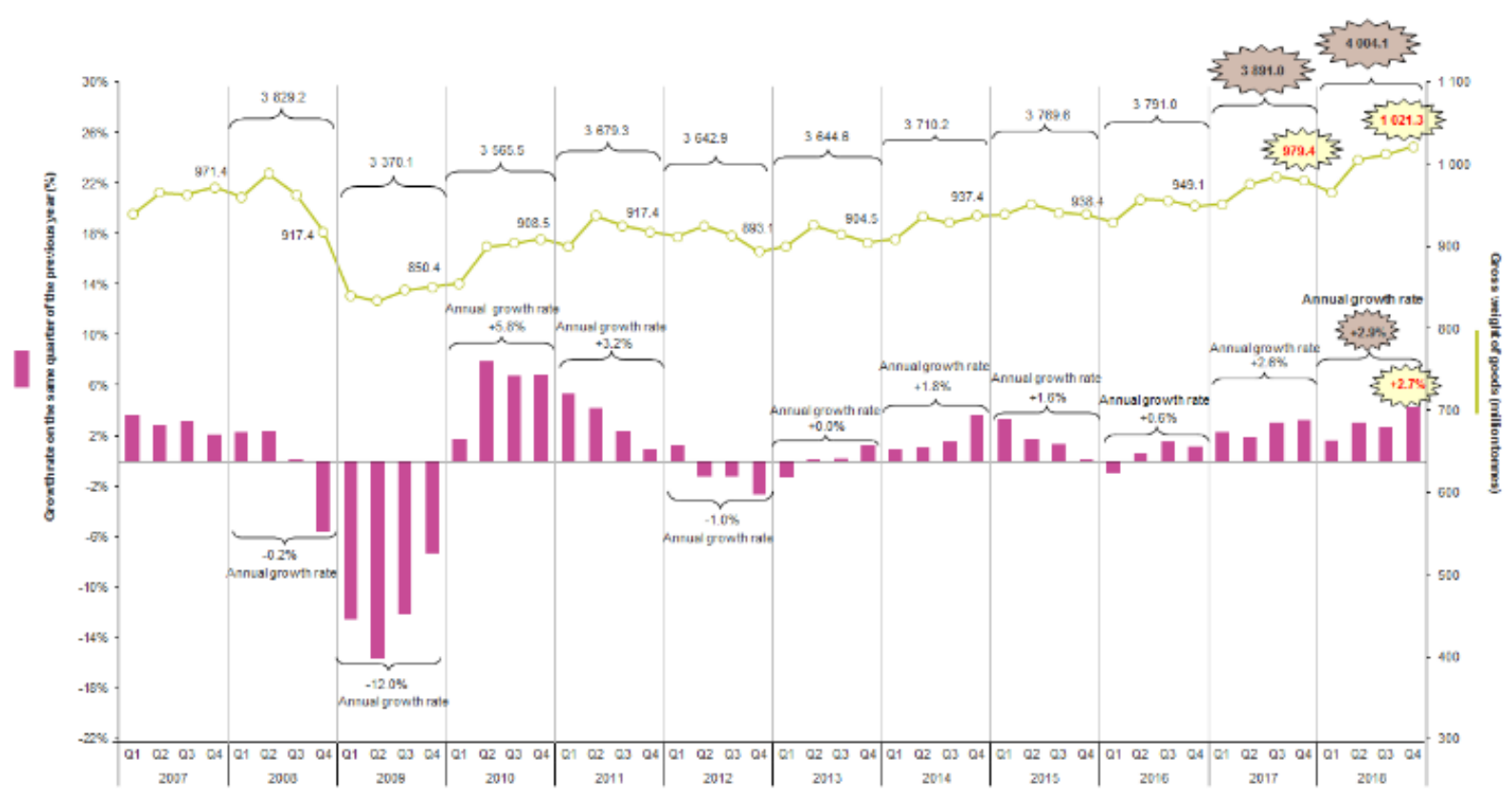

eurostat

Figure 2. The gross weight of seaborne in main ports of EU-28 (Eurostat, 2020)

\section{MARITIME TRANSPORT AND GREEN LOGISTICS}

Green Logistics describes all attempts to minimize the negative ecological impact of transportation and other activities connected to the internal and international flow of goods aiming to create a sustainable balance between economic and environmental issues. Green logistics has its origin in the mid-1980s and was a 
concept to characterize logistics systems and approaches that use advanced technology and equipment to minimize environmental damage during operations (Thiell, Zuluaga, Montanez, \& van Hoof, 2011). The approach towards green logistics requires transferring towards ecologically friendly modes of transport, among which waterborne transport as a major transport solution or in combined versions.

Green logistics has different components, but among them, the most important is green transport. The most important solutions in this area are the following:

- Route Optimization - cutting down travel costs, time, or distance, since the best chosen brings the possibility to save fuel and, consequently, to reduce the amount of $\mathrm{CO} 2$ emissions.

- Choosing the eco-friendliest transportation method available - it is important to choose more ecological options, like rail or maritime transportation.

Green logistics is a principle that modern logistics companies adhere to. Globally, carbon dioxide emissions need to be reduced. Green practices in modern logistics will contribute significantly to this reduction. This is especially important as the share of logistics services is constantly increasing. Green logistics is increasingly being implemented through so-called intermodal transport. It combines modes of transport to achieve more optimal routes and thus saves fuel and, consequently, reduce carbon emissions. Intermodal logistics solutions can be achieved by shuttle trains to ports where cargo containers are loaded in wagons for transportation to the destination

The state of waterborne transport in Bulgaria is estimated based upon statistical data of the National Association of Bulgarian forwarders (NSBS, 2019) as shown in Table 1.

Table 1 Maritime transport activity

\begin{tabular}{|r|r|c|r|r|r|r|}
\hline \multirow{2}{*}{} & \multicolumn{3}{|c|}{ Processed tonnage (tons) } & \multicolumn{3}{c|}{ Processed containers TEU } \\
\cline { 2 - 7 } & \multicolumn{1}{|c|}{ Import } & Export & \multicolumn{1}{c|}{ Transit } & Import & Export & \multicolumn{1}{c|}{ Transit } \\
\hline 2015 & 1051361 & 4454208 & 1105 & 53581 & 49344 & 3567 \\
\hline 2016 & 820581 & 4932269 & 32380 & 42558 & 36154 & 5824 \\
\hline 2017 & 1729480 & 4961974 & 90095 & 50856 & 36012 & 7544 \\
\hline 2018 & 2037324 & 3388723 & 103421 & 66375 & 52019 & 6497 \\
\hline
\end{tabular}

The analysis of the data indicated in Table 1 suggests a tendency towards increasing the number of goods processed included in the seaborne traffic of Bulgaria.

Table 2 Distribution of freight between different modes of transport in Bulgaria

\begin{tabular}{|c|r|r|c|r|r|}
\hline Years & \multicolumn{1}{|c|}{ Road } & \multicolumn{1}{c|}{ Rail } & Sea & \multicolumn{1}{c|}{ Air } & $\begin{array}{c}\text { Total goods } \\
(\mathbf{t})\end{array}$ \\
\hline 2015 Imports & 1942125 & 115024,5 & 1051361 & 6808.7 & 3115319 \\
\hline 2015 Exports & 1141344 & 1203793 & 4454208 & 4619.0 & 6803964 \\
\hline 2016 Imports & 1111670 & 1015985 & 820580,7 & 6459.4 & 954695 \\
\hline 2016 Exports & 938861 & 986659 & 4932269 & 6391.3 & 6864180 \\
\hline 2017 Imports & 1049994 & 899078 & 1729480 & 6809.8 & 3685362 \\
\hline 2017 Exports & 1342953 & 1080037 & 4961974 & 6748.4 & 7391712 \\
\hline 2018 Imports & 1601311 & 840569 & 2037324 & 5618.4 & 4484822 \\
\hline 2018 Exports & 1193788 & 1096098 & 3388723 & 6658.6 & 5685268 \\
\hline
\end{tabular}

The analysis of the data indicated in Table 2 suggests a tendency towards increasing the amount of goods processed included in the seaborne traffic of Bulgaria, compared with other 
modes of transport. Still, there are inequalities observed in the total volume of freight in the period observed.

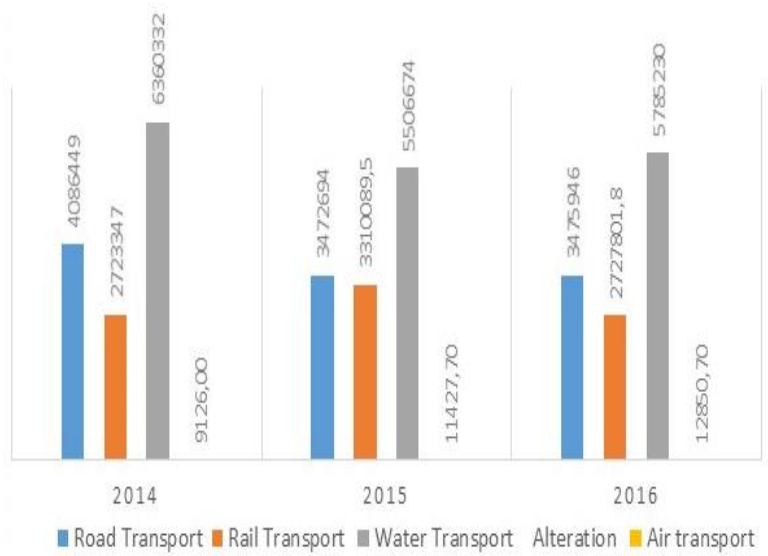

Figure 3. Distribution of freight by transport modes in Bulgaria

In connection with the increased use of maritime transport in the international logistic chains a Cargo Ferry concept has been developed to provide transport users with a better range of transport and logistics services through the development of new vessel concepts, new methods of loading and discharging, new traffic patterns and new IT solutions. The concept is aiming at the removal of the barriers for transferring freight from the road to the sea, particularly on short than $500 \mathrm{~km}$ distances, offering a cost-effective and more environmentally friendly alternative (Norbeck, 2016).

Bulgaria has developed traditions in ferryboat transport mainly for freight purposes. The Varna Ferry Complex is a part of the Varna Port Complex, operated by two national carries Shipping Company "Bulgarian Navy" and Bulgarian State Railways - Cargo, Ltd. It is the only transport facility in the European Union that allows the carriage of Russian wagons without overload, by changing the track from a standard European $(1435 \mathrm{~mm})$ to a Russian $(1520 \mathrm{~mm})$ track. With this unique advantage, the terminal provides some of the shortest and cheapest routes between Europe and Asia thanks to regular flights to llychevsk (Ukraine), Poti/Batumi (Georgia), and the Caucasus (Russia).

The transportation between Varna and Caucasus is already $80 \%$ of all traffic through the Ferry Complex. This line has been operating since 2009, shortening the distance between Bulgaria and Russia by 800 kilometers, reducing delivery times by $40 \%$.

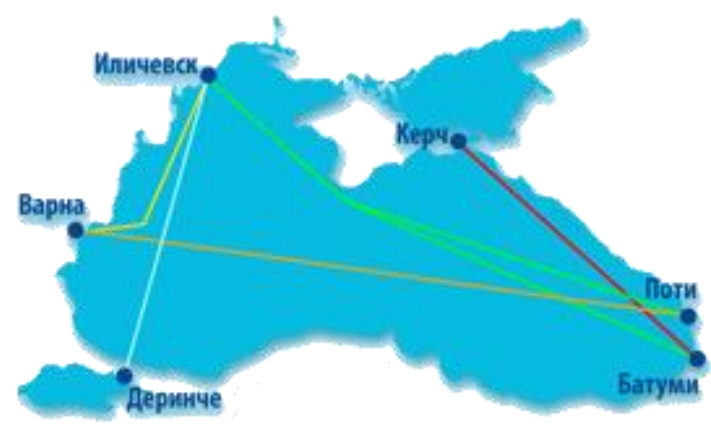

Figure 4. Direction on the sea routes between Black Seaports

Door-to-door service is available for all types of freight (railway wagons, trucks, and vans, containers, deck cargo, and passengers) to and from Belarus, Kazakhstan, Uzbekistan, Georgia, Armenia, Azerbaijan, Afghanistan, Turkey, Greece, Macedonia and Serbia by rail, sea, and land; from Europe to the Caucasus region and Central Asia, since the direction Varna - Ilychevsk - Poty/Batumi is a part of the international transport corridor TRASECA (Europe-CaucasusAsia). Still, notwithstanding the integration of the ferry line Varna - port Caucasus within the logistic chains between Europe and Asia, Bulgaria is far behind the EC in the development of multi-modal transport, and in particular, Varna Ferry Complex operates well below its operational capacity.

The statistics of the Ferry Complex in the port of Varna West shows that the main cargo is Propanbutane (more popularly called autogas), about 1755 railway tankers with 59898 tonnes of oil delivered from the Russian port of the Caucasus with the two ferry vessels annually. Propanebutane is supplied by Gaztrade, the largest importer of this fuel in our country. In addition to the importer, the company is also a railway carrier and loads the OMV chain, Fuel, and other dealers. Propane-butane accounts for over $92 \%$ of goods imported from Russia. Besides, from the Caucasus port arrive also petroleum products, mainly base oils (about 47 railway tanks with 2546 tons of petroleum products annually). Third in import is cereals, mainly ripe beans. Few machines and equipment are imported along the ferry line - 4 wagons (53t), as well as 15 other goods wagons - a total of 867 tonnes. The VarnaCaucasus ferry line is one of the main prerequisites for maintaining and even increasing 
the turnover and revenues of the Port of Varna in recent years. Almost immediately after the opening of the line in March 2009, it proved to be the most direct, fast, and inexpensive route for trade between Bulgaria and Russia, but there is a significant foreign trade deficit in the trade between Russia and Bulgaria.

The export items to the Caucasus are mainly construction materials - 28 cars (1832 tons), food products - 15 cars (561 tons), machinery and equipment - 11 cars (559 tons), cosmetics - 10 cars (395 tons) and other goods, such as polymers, magnesite, wood boards, base oils, etc. Part of the export to Russia is due to cargo volumes delivered from Turkey since a direct ferry connection with Russia for freight carried by wagons is missing.

On the other hand, the Varna-Caucasus line is not integrated into a single, continuous door-to-door chain, especially for shipments in the range between 20 tonnes and a block train ( 800 tonnes), so the service is currently limited in use only the Varna-Caucasus-Asia section and only for traditional rail customers. The services of the Varna-Caucasus ferry could be sold to third parties, especially in the South-North direction, specifically Greece - Russia, and Turkey - Russia. Also, the unexplored market is the freight for the Scandinavian countries through the Varna Caucasus-Saint Petersburg line, especially for Finland. There are prerequisites for this because of the high infrastructure costs in Romania and, in principle, the high prices for road transport only from Bulgaria but also from Greece and Turkey, especially for agricultural machines' transportation (Norbeck, 2016).

\section{CONCLUSION}

Among the measures, recommended by the Integrated Transport Strategy of Bulgaria until 2030 (Eurostat, 2020) is the development of transport schemes and technologies to respond to the contemporary environmental and climate requirements.

To fully realize the potential of the above principles and opportunities, as far as the ferry boat line is concerned, the following possible steps need to be taken:

- Implementation of a unified tariff policy by Russian Railways and Bulgarian operators.

- Creating an integrated product to the final recipient, based on strategic partnerships between customers, shippers, and carriers.

- Attracting private wagons along the Greece/ Bulgaria-Russia line of the Varna-Caucasus Ferry, using reverse load options.

- Application of technology for specialized transportation (e.g. of refrigerated containers); - Integrate the Varna-Caucasus ferry into a future container rail line between Western China and Southern Europe. This will reduce the transit time by one week and enter the segment of high-interest parcels and will have competitive advantages over seafarers and Northern European ports.

Bearing in mind the role of combined transport of containers within and outside Europe, the potential of the ferryboat line between the ports of Varna and Caucasus has got potential for future development, bringing forward economic advantages to all the participating partners.

\section{WORKS CITED}

EC. (21.1.2019). Strategic goals and recommendations for the EU's maritime transport policy until 2018 - Communication from the Commission to the European Parliament, the Council, the European Economic, and Social Committee and the Committee of the Regions (COM(2009) 8 final изд.). Brussels: European Commission. doi:https://eurlex.europa.eu/LexUriServ/LexUriServ.do?uri=COM\%3A2009\%3A0008\%3AFIN\%3AEN\%3AP $\mathrm{DF}$

EC. (30.9.2016). Commission Staff Working Document on the implementation of the EU Maritime Transport Strategy 2009-2018 (SWD (2016) 326 final ed.). Brussels: European Commission. Retrieved from https://ec.europa.eu/transport/sites/transport/files/swd2016_326.pdf

Eurostat. (2020). Eurostat maritime transport data. Retrieved from European Commission: https://ec.europa.eu/eurostat/web/transport/data/database 
Norbeck, J. A. (2016, 03 30). Cargo Ferry (GodsFergen) - a new sea transport concept. Retrieved from SINTEF: https://www.sintef.no/en/projects/cargo-ferry-godsfergen-a-new-sea-transportconcept/

NSBS. (2019). Statistical data of National association of Bulgarian forwards. Retrieved from NSBS: https://nsbs.bg/uploads/content/\%d0\%9e\%d0\%b1\%d0\%be\%d0\%b1\%d1\%89\%d0\%b5\%d0\%b d\%d0\%b0\%d0\%a1\%d1\%82\%d0\%b0\%d1\%82\%d0\%b8\%d1\%81\%d1\%82\%d0\%b8\%d0\%ba\% d0\%b0_\%d0\%9d\%d0\%a1\%d0\%91\%d0\%a1_2015-2018.pdf

Rodrigue, J.-P., \& Notteboom, T. (2017, 11 04). Maritime Transportation. Retrieved from The Geography of Transport Systems: https://transportgeography.org/?page_id=1762

Thiell, M., Zuluaga, J., Montanez, J., \& van Hoof, B. (2011). Green Logistics - Global Practices and their Implementation in Emerging Markets, p. 2. In Z. Luo, Green Finance and Sustainability: Environmentally-Aware Business Models and Technologies (pp. 334-357). Universidad de los Andes, Colombia. Retrieved from https://www.igiglobal.com/viewtitlesample. aspx ? id $=53259 \&$ ptid $=45895 \& \mathrm{t}=$ The\%20Impact\%20 of\%20Sustaina bility-Focused\%20Strategies\%20on\%20Sourcing\%20Decisions\&isxn=9781609605315

Received for publication:

Revision received:

Accepted for publication:
22.01.2020

31.03 .2020

01.07 .2020

\section{How to cite this article?}

Style - APA Sixth Edition:

Kirova, A. (2020, July 15). Prospects of maritime transport in the establishment of "green" logistics chains. (Z. Cekerevac, Ed.) MEST Journal, 8(2), 107-113. doi:10.12709/mest.08.08.02.11

Style - Chicago Sixteenth Edition:

Kirova, Antoaneta. 2020. "Prospects of maritime transport in the establishment of "green" logistics chains." Edited by Zoran Cekerevac. MEST Journal (MESTE) 8 (2): 107-113. doi:10.12709/mest.08.08.02.11.

Style - GOST Name Sort:

Kirova Antoaneta Prospects of maritime transport in the establishment of "green" logistics chains [Journal] // MEST Journal / ed. Cekerevac Zoran. - Belgrade - Toronto : MESTE, July 15, 2020. - 2 : Vol. 8. - pp. 107-113.

\section{Style - Harvard Anglia:}

Kirova, A., 2020. Prospects of maritime transport in the establishment of "green" logistics chains. MEST Journal, 15 July, 8(2), pp. 107-113.

Style - ISO 690 Numerical Reference:

Prospects of maritime transport in the establishment of "green" logistics chains. Kirova, Antoaneta. [ed.] Zoran Cekerevac. 2, Belgrade - Toronto : MESTE, July 15, 2020, MEST Journal, Vol. 8, pp. 107113. 